DOI https://doi.org/10.30525/978-9934-26-007-0-25

\title{
LEGISLATIVE PROVISION OF HUMAN RIGHT TO HEALTH: COMPARATIVE AND LEGAL ASPECT
}

\author{
Shevchenko A. Ye., Kudin S. V.
}

\section{INTRODUCTION}

Significant deterioration of the environment in Ukraine in the last quarter of the XX - early XXI century associated with a range of problems: a number of manmade accidents, air pollution due to industrial waste and increased use of vehicles, deteriorating environmental status of water resources, etc., combined with deteriorating food quality, unhealthy lifestyle, unsatisfactory situation in in the field of health care - has led to an increase in the number of sick citizens, reducing life expectancy among Ukrainians (as of May 2018, it is the lowest in Europe; the average age of women is 77 years, men -67$)^{1}$. The draft Concept for building a new national health care system in Ukraine states that Ukraine has one of the worst performance among health care systems in the European region, and is in second place in terms of mortality (14.9 per 1,000 population), which has increased by $12.7 \%$ over the last 20 years, while in the European Union this figure decreased by $6.7 \%^{2}$. In addition, the situation has significantly deteriorated due to the rapid spread in 2020 in the world and in Ukraine of coronavirus infection COVID-19 (for example, in Ukraine on November 6, officially registered 440188 cases of infection) ${ }^{3}$.

Therefore, the deteriorating demographic situation in Ukraine should be noted. At present, it is not only about improving it, but also preserving the nation's gene pool, which also affects Ukraine's national security, because "the creation of an effective human rights mechanism is a guarantee of minimizing threats to Ukraine's national security, which is especially important in today's challenges"4.

The above actualizes the solution of the problem of ensuring the human right to health, first of all - at the constitutional level, as well as the creation of an effective mechanism for the implementation of this right. Thus, Section II of the

\footnotetext{
${ }^{1}$ Тривалість життя українців все ще найнижча в Свропі - соціолог. URL : https://www.radiosvoboda.org/ a/29256907.html.

2 Проект Концепції побудови нової національної системи охорони здоров'я України від 07.08.2014 року. URL : http://oblzdrav.mk.gov.ua/index.php/gromadska-rada/obgovorennya/6220-kontseptsiya-pobudovi-novojinatsionalnoji-sistemi-okhoroni-zdorov-ya-ukrajini.

${ }^{3}$ Оперативна інформація про поширення коронавірусної інфекції 2019-nCoV. URL : https://moz.gov.ua/ article/news/operativna-informacija-pro-poshirennja-koronavirusnoi-infekcii-2019-ncov.

${ }^{4}$ Шевченко А.С., Кудін С.В. Розвиток прав людини в Україні та їх захист державою. Матеріали міжнародної науково-практичної конференції «Права людини інаціональна безпека: роль органу конституційної юрисдикцї̈» (м. Київ, 27 червня 2019 р.). Київ : КНУ імені Тараса Шевченка. С. 346.
} 
Basic Law of Ukraine enshrined natural, political, social, economic, cultural, family, environmental, informational and other human and civil rights and freedoms in Ukraine 5 .

At the same time, Ukraine's desire to join the EU, as evidenced by the signing of the Association Agreement between Ukraine and the European Union of March 21 and June 27, 2014, is reflected in the need to pay attention to the experience of enshrining the constitutional foundations of human rights to health in countries belonging to the European Union.

In this context, in our opinion, a comparative analysis of the constitutional principles of ensuring the human right to health in Ukraine and in such states as the Czech Republic and the Republic of Poland should be carried out. The reason for choosing the constitutions of these countries is that, firstly, like the Ukrainian SSR, they were for some time in the Soviet political and legal system, secondly, they are among the consistent supporters of Ukraine's accession to the EU, and thirdly, we unite the ancient historical relations of friendship and cooperation, and in the legal sphere - the mutual reception of legislation, their adaptation to local conditions.

\section{Legislative framework on ensuring the human right to health in Ukraine}

Article 3 of the Constitution of Ukraine of 1996 states that "A person, his life and health, honour and dignity, inviolability and security are recognized in Ukraine as the highest social value. Human rights and freedoms and their guarantees determine the content and direction of the state. The state is accountable to man for his activities. The promotion and protection of human rights and freedoms is the main duty of the state" ${ }^{\prime 6}$. From this fundamental principle, the logic of constructing sections of the Basic Law of Ukraine according to the priorities of the functions of the state, strategic and tactical goals of its activity naturally follows. That is why the rights, freedoms and responsibilities of man and citizen are enshrined in Section II. Today, the constitutional enshrinement of human rights and freedoms as the highest value and their compliance with international law is one of the important features of a democratic state, so the inalienable and inviolable right of every person is the right to health care ${ }^{7}$.

Since the right to health belongs to the group of inalienable rights, it is natural that the legislator paid attention to its constitutional provision in the first articles of Section II. Thus, Article 27, paragraph 3, states that "Everyone has the right to

\footnotetext{
${ }^{5}$ Anatolii Shevchenko, Olena Kalhanova, Serhii Kudin \& Olena Kravchenko. Guarantees of realization of the rights and freedoms of the person in the national legal system: teaching technique. Asia Life Sciences. The Asian International Journal of Life Sciences. Supplement 21(2) 2019. S. 535.

${ }^{6}$ Конституція України від 28 червня 1996 року. URL : https://zakon.rada.gov.ua/laws/show/254к/96-вр/.

${ }^{7}$ Руснак Л.М. Адміністративно-правове забезпечення права на охорону здоров'я в Україні : дис. ... канд. юрид. наук. Київ, 2016. С. 25.
} 
the protection of his life and health, the life and health of others from unlawful encroachment". Article 28, while not explicitly defining the right to health, nevertheless follows from the legal analysis of its text that the State seeks to ensure that right: "No one shall be subjected to torture or to cruel, inhuman or degrading treatment or punishment. No person may be subjected to medical, scientific or other experiments without his or her free consent" (parts 2 and 3$)^{8}$.

Other rights are closely linked to the right to health. In particular, paragraphs 1-3 of Article 49 state that "Everyone has the right to health care, medical assistance and medical insurance. Health care is provided by state funding of relevant socioeconomic, health and health prevention programs. The state creates conditions for effective and accessible medical care for all citizens. Medical care is provided free of charge in state and municipal health care facilities; the existing network of such establishments cannot be reduced. The state promotes the development of medical institutions of all forms of ownership"".

The human right to health is also enshrined in other normative legal acts, which are constitutional in nature, as they detail the relevant articles of the Constitution. These, in particular, are: the Law of Ukraine "Fundamentals of the legislation of Ukraine on health care" (as amended on 29.12.2019) (which deals with: recognition of the priority of international legal acts (Article 2); meaning of definitions and terms used in the legislation on health care (health, medical care, medical care, medical service, health care, etc.) (Article 3); formulation of basic principles of health care (Article 4); other basic principles $)^{10}$, the Law of Ukraine "On ensuring the sanitary and epidemiological well-being of the population" (as amended on 04.10.2018) (emphasize: the definition of basic terms and concepts contained in Article 1, in particular, the environment of human life, adverse effects on human health, sanitary and epidemiological situation, safety requirements for human health and life, favourable living conditions etc.; strengthening the right of citizens to safe for health and life food, drinking water, working conditions, education, upbringing, life, recreation and the environment, participation in the development, discussion and public examination of draft programs and plans to ensure sanitary and epidemiological well-being, making proposals on these issues to the relevant authorities, compensation for damage caused to their health as a result of violations of enterprises, institutions, organizations, citizens of sanitary legislation and others $)^{11}$.

\footnotetext{
${ }^{8}$ Конституція України від 28 червня 1996 року. URL : https://zakon.rada.gov.ua/laws/show/254к/96-вр/.

${ }^{9}$ Там само.

10 Закон України «Основи законодавства України про охорону здоров’я» від 19.11 .1992 р. в редакції від 29.12.2019 p. URL : https://zakon.rada.gov.ua/laws/show/2801-12.

11 Закон України «Про забезпечення санітарного та епідеміологічного благополуччя населення» від 24.02.1994 р. в редакції від 04.10.2018 p. URL : https://zakon.rada.gov.ua/laws/show/4004-12.
} 
At first glance, the constitutional provision of the human right to health in Ukraine is quite thorough. Thus, the domestic legal scientific literature defines, based on the text of relevant laws, such rights of citizens in the field of health care as the right to preventive measures, the right to access, the right to information, the right to consent, the right to freedom of choice, the right to privacy and confidentiality, the right to security, the right to an individual approach to treatment, the right to file a complaint, the right to compensation, etc. ${ }^{12}$.

However, a number of Ukrainian scholars and legal practitioners rightly draw attention to significant gaps in the clarity of definition of certain concepts and terms contained in domestic legislation, which should reveal the essence of the legal framework for ensuring the right to human health, as well as the need to update existing legislation in the context of medical reform in Ukraine, launched in 2017. And this, in turn, affects both the authentic interpretation of public authorities, local governments, judicial institutions of the relevant regulations, and the unimpeded exercise by citizens of Ukraine of their legal rights.

Such gaps scientists call:

1) there is no clear distinction between the content of the right to health care and medical assistance; insufficient definition of the difference in the concepts of "medical care" and "medical service", as well as the lack of settlement of issues of free or paid medical care to such groups of entities as foreigners; unclear definition of "public health management" and "public health", as well as the absence of some important concepts in the current constitutional and legal framework (for example, "single medical space"); imperfection and inconsistency with the new realities of life of the constitutional and legal consolidation of guarantees for the realization of the human right to health; slow improvement of legal consolidation of stages of medical reform in Ukraine; imperfection of the definitions of "active euthanasia" and "passive voluntary euthanasia"; "the constitutional right to health care and medical assistance in Ukraine (Article 49 of the Constitution of Ukraine) does not fully comply with basic international legal standards, as in international treaties to which the Ukrainian state is a party, this right is considered much more broadly, and includes the social well-being of man"13.

\footnotetext{
${ }^{12}$ Права людини в сфері охорони здоров'я та форми їх захисту. URL : http://korosten-rada.gov.ua/ sotsialniy-rozvitok/ohorona-zdorovya/tsentralna-miska-likarnya/prava-lyudini-v-sferi-ohoroni-zdorovya/.

${ }^{13}$ Конституційне закріплення права на охорону здоров'я. Порівняльний аналіз конституційної практики. URL : http://bkb-law.com.ua/index.php?option.

Швець Ю. Зміст конституційного права особи на охорону здоров'я. Підприємництво, господарство $i$ право. 2017. № 8. С. 136.

Лещенко В. В., Радиш Я. Ф. Права людини на життя та охорону здоров'я - методологічна основа державного управління здоровоохоронною сферою: вступ до проблеми. Державне управління: теорія та практика. 2014. № 1. С. 112.

Назарко Ю. В. Гарантії реалізації права на охорону здоров’я в Україні та країнах Свропейського Союзу. Юридичний часопис Національної академї внутрішніх справ. 2018. № 1(15). С. 412.
} 
The domestic scientific literature provides ways to solve these problems, mainly in attempts to provide authorial definitions of such concepts as "the right to health care", "the right to medical care", "medical service", "single medical space", etc., it is offered to improve the constitutional and legal consolidation of guarantees for the realization of the human right to health and other. The fact that scientists justify their position by the need to pay attention to the international and European experience of the constitutional consolidation of the human right to health is quite positive.

Logically, the need to take into account the experience of the European Union is based on the main provisions of various projects of public authorities, independent public organizations and legal documents that should determine the fundamental principles of building human health in Ukraine (this is, in particular, the Draft Concept of building a new national health care system of Ukraine, presented by the Ministry of Health of Ukraine on 07.08.2014, the National Strategy for building a new health care system in Ukraine for the period 2015 2025, developed by the Strategic Advisory Group on Health Care Reform in Ukraine (SAG on health care), which was created by the Order of the Ministry of Health № 522 of 24.07.2014, Resolution of the Verkhovna Rada of Ukraine On Recommendations of parliamentary hearings on the topic: "On health care reform in Ukraine" from 21.04.2016, the Concept of building a new national health care system of Ukraine, announced by the Independent Expert Platform "PRO S VITA" on 08.11.2017 and others ${ }^{14}$ ).

In connection with the proclamation of the WHO pandemic in the world (COVID-19), the Ukrainian state has intensified its activities aimed at protecting the health of its citizens. The basic normative documents have become the Law of Ukraine "On amendments to certain legislative acts of Ukraine aimed at preventing the occurrence and spread of coronavirus disease (COVID-19)"

Роханський А. Права людини в галузі охорони здоров’я. URL : https://helsinki.org.ua/prava-lyudyny-vhaluzi-ohorony-zdorov-ya-a-rohanskyj/.

Шамич O.M. Співвідношення права людини на охорону здоров'я і права на життя в Україні. Актуальні проблеми навчання та виховання людей з особливими потребами. 2015. № 12. С. 228-229.

Шекера О.Г. Конституційні основи охорони здоров'я громадян в Україні. Збірник наукових праць співробітників НМАПО імені П.Л. Шупика. 2013. № 22(4). С. 530.

${ }^{14}$ Проект Концепції побудови нової національної системи охорони здоров'я України від 07.08.2014 року. URL : http://oblzdrav.mk.gov.ua/index.php/gromadska-rada/obgovorennya/6220-kontseptsiya-pobudovi-novojinatsionalnoji-sistemi-okhoroni-zdorov-ya-ukrajini.

Національна стратегія побудови нової системи охорони здоров’я в Україні на період 2015-2025 років, розроблена Стратегічною дорадчою групою з питань реформування системи охорони здоров'я в Україні. URL : https://healthsag.org.ua/wp-content/uploads/2014/11/Proekt-Strategiyi-reformi_OZ.pdf.

Постанова Верховної Ради України «Про Рекомендації парламентських слухань на тему: «Про реформу охорони здоров’я в Україні» від 21.04.2016 року. URL : https://zakon.rada.gov.ua/laws/show/1338-19.

Концепція побудови нової національної системи охорони здоров'я України, анонсована Незалежною експертною платформою «ПРО S VITA» 08.11.2017 року. URL : https://www.ukrinform.ua/rubricpresshall/2335458-nova-nacionalna-sistema-ohoroni-zdorova-ukraini-koncepcia-vid-pro-s-vita.html. 
№ 533-IX of 17.03.2020, resolution of the Cabinet of Ministers of Ukraine "On prevention of the spread of coronavirus disease (COVID-19) on the territory of Ukraine" № 211 from 11.03.2020 and some others (as of the beginning of November 2020 more than 50 such documents).

The main measures to ensure the right of citizens to health are: quarantine, with a ban on visiting educational institutions by its applicants, holding all mass events involving more than 200 people, except for measures necessary to ensure the work of public authorities and local governments, sports events are allowed to be held without the participation of spectators (fans), it is forbidden to stay in public places without wearing personal protective equipment, moving a group of more than two people, except in cases of business necessity and accompanying persons under 14 by parents, adoptive parents, guardians, trustees, foster parents, caregivers, other persons in accordance with the law or adult relatives of the child, visiting parks, squares, recreation areas, forest parks and coastal areas, except for walking pets alone and in case of business, visiting sports and playgrounds, etc.

Despite the threatening situation in Ukraine (rapid spread of the disease, lack of necessary funds and medicines), Ukrainian citizens (volunteers, patrons, business representatives and others) found an opportunity to provide assistance to medical institutions and doctors in Ukraine. In addition, our doctors were able to provide assistance to colleagues in the EU (in particular, Ukrainian doctors for three weeks provided all possible assistance in combating the spread of infectious diseases (COVID-19) in the Italian Republic), and they joined the protocols of medical care, which will allow in the future to use this European experience in our country during the fight against the pandemic.

\section{Constitutional principles of ensuring the human right to health in the Republic of Poland and the Czech Republic}

In connection with the above, it is appropriate to pay attention to the provisions that enshrine the right to health in the constitutions of the two states. As in the Constitution of Ukraine, the Constitution of the Republic of Poland of April 2, 1997 affirms the principle of the state's concern for the inviolability of the rights and freedoms of citizens. This follows, in particular, from Article 5: "The Republic of Poland guards the independence and inviolability of its territory, ensures the freedoms and rights of man and citizen, the security of citizens, guards the national heritage, and ensures the protection of the environment, guided by the principle of balanced development" ${ }^{\prime 15}$. It naturally follows that in the Constitution of the Republic of Poland, as well as in the Constitution of

\footnotetext{
${ }^{15}$ Конституція Польської Республіки (з передмовою Володимира Шаповала). Київ : Москаленко О.М., $2018.84 \mathrm{c}$.
} 
Ukraine, freedoms, rights and obligations of man and citizen are contained in Section II.

Interestingly, as in the Constitution of Ukraine, the right to health is not directly defined, but the legal analysis of the text of the Constitution of the Republic of Poland implies the state's efforts to ensure this right. In Article 39 states that "No one may be subjected to scientific experiments, including medical, without free consent", and in Article 40 - that "No one shall be subjected to torture or to cruel, inhuman or degrading treatment or punishment. The use of corporal punishment is prohibited"16.

At the same time, the peculiarity of the Constitution of the Republic of Poland is that it reflects the position of the state on consolidating the typology of human and civil rights and freedoms. Thus, the right to health is included in the subsection "Personal freedoms and rights", while the right to health care is included in the subsection "Economic, social and cultural freedoms and rights". Moreover, in the Constitution of the Republic of Poland, the norm on the right to health care, in our opinion, is spelled out more clearly, especially, first, in terms of the obligations of the state to ensure this right; secondly, the obligation of the state to take care of the health of the vulnerable for one reason or another. In Article 68 states that "1. Everyone has the right to health. 2. Citizens, regardless of their financial situation, shall be granted equal access by public authorities to public care financed by public funds. The conditions and scope of medical care are determined by law. 3. The public authorities are obliged to take special care of the health of children, pregnant women, people with physical and mental disabilities and the elderly. 4. Public authorities have a duty to combat epidemic diseases and to prevent the negative health consequences of environmental degradation. 5. Public authorities support the development of physical culture, especially among children and youth" ${ }^{\prime 17}$.

The responsibilities of the state to ensure the protection of the natural environment are also more clearly defined. In particular, in Article 74 states that "1. Public authorities pursue policies that ensure environmental security for present and future generations. 2. Environmental protection is the responsibility of public authorities. 3. Everyone has the right to information about the state of the environment and its protection. 4. Public authorities support the actions of citizens aimed at protecting the environment and improving its condition" ${ }^{\prime 18}$.

The collapse in the late 80's of the XX century of "socialist camp", the adoption of the Constitution of the Republic of Poland and the Constitution of the Czech Republic initiated a number of significant changes in the health of citizens of these states. First of all, this is due to a number of reforms in the medical field,

\footnotetext{
${ }^{16}$ Конституція Польської Республіки (з передмовою Володимира Шаповала). Київ : Москаленко О.М., 2018. 84 c.

17 Там само.

18 там само.
} 
and this experience is useful for Ukraine, where the departure from the "Semashko model" (financing only through taxation, strict centralization, full free health care), unlike our neighbours, occurs only in 2017.

The reform in the field of human and civil health in the Republic of Poland was carried out during 1997-2003. Thus, in 1997 the Law on General Health Insurance was adopted, and at the same time - the Social Health Insurance System was created, as well as 17 funds of health insurance; in 2003, these funds were replaced by the People's Health Fund, which is funded from the state budget (the Beveridge model). "Currently, almost $98 \%$ of the population is covered by the Social Health Insurance System (SHI), which is mandatory for most citizens" $"$.

According to experts, "Poland has built funding for medicine on the principle of joint and several compulsory health insurance. The payer for medical services and medicines is the National Health Fund, which is replenished through individual tax deductions. They are carried out, first of all, by workers and businessmen. But even those who receive unemployment benefits are required to make such deductions" ${ }^{20}$. It is clear that the deductions of these entities are different in terms of their money supply, but according to the Constitution of the Republic of Poland, access to medical services provided by state medical institutions is equal for all (in the Republic of Poland all hospitals are divided into three types: public (usually large and medium), private, and those owned by local governments).

An important problem, the solution of which is also relevant for Ukraine, is the dilemma: further centralization (Soviet model) or decentralization of the entire health care system. In the Republic of Poland, the public administration of the health care system complies with the generally accepted norms of the European Union on the desired decentralization of such administration. That is why the management of the health care system is divided between the Ministry of Health, the People's Health Fund and local governments. The Ministry of Health sets national policies and provides funding for long-term health goals. The People's Health Fund deals with the distribution of funding among the insured population. Local authorities are responsible for providing local health services, hospitals and paying for services, and organizing doctors.

It is clear that any reform is not carried out for the sake of the reform itself, but to improve the lives of citizens. The experience of the Republic of Poland (despite the existing problems, of course) on health care reforms is quite indicative: for example, in 2009 the total life expectancy of women was $80 \%$ and men $71.6 \%$ (in Ukraine - respectively 77 and 67\%).

\footnotetext{
${ }^{19}$ Чмель О., Пустовойт Д., Шмігель А. Аналіз системи охорони здоров'я в Польщі. Сучасні економічні дослідження. 2018. № 1. Вип. 1. С. 14.

20 Даневич Б. Медицинская реформа: полезный опыт Польши для Украины (17 октября 2017 г.). URL : https://www.pravda.com.ua/rus/columns/2017/10/17/7158694/.
} 
The spread of infectious coronavirus disease also affected the Republic of Poland, and the first cases of the disease in this country and in Ukraine were recorded in early March (as of November 6 in the Republic of Poland the number of infected is about 546 thousand). It should be noted that the authorities of our neighbour reacted quickly enough, because every day of inaction could lead to an unpredictable situation. Thus, on March 6, President A. Duda signed a special law to combat the spread of coronavirus. Its text contains normative prescriptions, which in principle are similar to the prescriptions of the Ukrainian legislation: patients with coronavirus, as well as persons suspected of having COVID-19 may be subject to additional hospitalization. The law also states that in order to counteract the spread of coronavirus, the employer may instruct the employee to do work from home ${ }^{21}$. In addition, quarantine was introduced in the Republic of Poland, and from 1.04. the regime was significantly strengthened, from 09.04. introduced a "mask mode" (still valid today). Thus, in our opinion, we can see similar processes of normative consolidation of measures that should contribute to the fight against the spread of coronavirus, both in Ukraine and in the Republic of Poland.

The Constitution of the Czech Republic of 16 December 1992 is specific in the sense that it lacks, as in the "traditional" constitutions of the world, a section on the rights, freedoms and responsibilities of man and citizen. This can be explained by the fact that the Constitution consists, in fact, of two constitutional acts: the Constitution itself, and the Charter of Fundamental Rights and Freedoms of January 9, 1991, which is an integral part of the Constitution in accordance with Article $3^{22}$.

The structure of this Charter is similar to the section on freedoms, rights and responsibilities of man and citizen of the Constitution of the Republic of Poland: it is also built on the principle of typology of rights and freedoms, and with the mentioned Constitution and the Constitution of Ukraine it is united by the formal uncertainty of the concept of "right to health". Nevertheless, as in the two constitutions mentioned, the Charter enshrines the state's efforts to ensure this right. Thus, in paragraph 2 of Article 7 (Section I "Fundamental Rights and Freedoms" of Chapter II "Human Rights and Fundamental Freedoms") states that "No one shall be subjected to torture or to cruel, inhuman or degrading treatment or punishment" 23 .

As in the Constitution of the Republic of Poland, the Charter places the right to health care in the chapter II "Economic, Social and Cultural Rights", as well as the rights of the vulnerable population. In particular, in accordance with Article 31 "Everyone has the right to health. On the basis of public insurance, citizens have the right to free medical care and medical benefits under the conditions established

\footnotetext{
${ }^{21}$ Президент Польщі підписав спецзакон про боротьбу із коронавірусом. URL : https://nv.ua/ukr/world/ countries/koronavirus-u-polshchi-prezident-pidpisav-speczakon-pro-borotbu-z-covid-19-50074399.html/.

${ }^{22}$ Конституция Чехии (Чешской Республики) от 16 декабря 1992 года. URL : https://czholding.ru/aboutcz/konstitucija-chehii/.

${ }^{23}$ там само.
} 
by law", paragraphs 1 and 2 of Article 29 "Women, youth and persons with disabilities have the right to increased health protection at work and special working conditions"; "Young people and people with disabilities have the right to special protection in labour relations and to assistance in mastering a profession" 24 .

The Charter, as well as the Constitution of Ukraine and the Constitution of the Republic of Poland, enshrines the desire of the state to ensure the right of man and citizen to a safe environment. In particular, paragraphs 1 and 2 state that "Everyone has the right to a favourable environment"; "Everyone has the right to timely and complete information on the state of the environment and natural resources" 25 .

The health care system in the Czech Republic is similar to that established in the Republic of Poland and is based on the principle of decentralization of the health care system as well as compulsory health insurance (the Bismarck model). In the late 80 's - early 90's of the twentieth century, there was a privatization of many institutions providing medical services to the population. However, this does not mean the abolition of free medical care, because Article 31 of the Charter of Fundamental Rights and Freedoms of 9 January 1991 stipulates that such assistance is provided by public insurance.

As in the Republic of Poland, the financing of the medical sphere is carried out on the principle of joint and several compulsory health insurance. The health care system is "funded by contributions from individuals and employers. At the end of 2011, there were 8 public health insurance funds (PHIF). PHIF is a kind of legal entity with the status of a public, non-profit entity, but such organizations are independent of the state and have their own budgets. The state pays contributions for all economically inactive citizens, including the unemployed, pensioners, children, students and women on maternity leave, who together make up more than half of the total population. Any person with permanent residence in the Czech Republic is entitled to health insurance" 26 .

The organization of health care management is also similar to that established in the Republic of Poland. Thus, "centralized management of the industry is carried out by the Ministry of Health, which ensures the unified management of the state health care system and issues regulations that are binding. The second participant in the process of providing medical care in the Czech Republic are health insurance funds. The largest among them is the General Health Insurance Fund, the founder and guarantor of which is the state". Finally, the third participant is "a wide network of health facilities that have several forms of ownership: private

\footnotetext{
${ }^{24}$ Конституция Чехии (Чешской Республики) от 16 декабря 1992 года. URL : https://czholding.ru/aboutcz/konstitucija-chehii/.

${ }^{25}$ Там само.

${ }^{26}$ Достал О. Міжнародний досвід реформування первинної медичної допомоги у Чехії. URL https://www.umj.com.ua/article/22698/mizhnarodnij-dosvid-reformuvannya-pervinnoi-medichnoi-dopomogi-chexiya.
} 
(outpatient care - self-practitioners and their associations - clinics, primary care centers); state - inpatient medical care (hospitals, university clinics)",27.

We can state that as a result of health care reforms, for example, in 2013 the total life expectancy of women was almost $81 \%$, and men $-75 \%$ (total life expectancy increased compared to the early 90 s of the twentieth century, and the population is stable (although not taking into account migration processes).

The Czech Republic is also at the epicenter of the spread of coronavirus ${ }^{28}$ (as of November 6, the number of patients increased to 411 thousand). For the first time, the presence of infected people was recorded on March 1, and the rapid growth of patients forced the Government of the Czech Republic, in contrast to the Republic of Poland and Ukraine, to impose a state of emergency on March 12 for a period of 30 days and impose quarantine, which halted the spread of infection. In addition, rather high fines were imposed for violating the conditions of quarantine (in terms of the Ukrainian hryvnia - about 3 million 330 thousand hryvnias). 25.03. the Ministry of Health of the Czech Republic imposed stricter quarantine conditions, which were extended from October 22, $2020^{29}$.

\section{CONCLUSIONS}

1. Legislative support for the right to human health in Ukraine is contained not only in the Basic Law, but also in a number of constitutional and legal acts. The analysis of the relevant norms shows the lack of perfection of definitions of concepts and terms that should reflect this right. Other problems are: the lack of a sustainable Concept for building a new national health care system in Ukraine, the slow pace of health care reform, and the departure from the Soviet centralized system of public health management, and more.

2. The Constitutions of Ukraine, the Republic of Poland and the Czech Republic have common features in formulating the constitutional principles of ensuring the human right to health: the principle of state concern for the inviolability of human rights and freedoms, the state's efforts to formulate human rights to health and associated with the right to health care, for the most part - the unity of terminology. At the same time, the Constitution of the Republic of Poland and the Constitution of the Czech Republic reflect the desire to typologize the rights and freedoms of man and citizen (and the Constitution of the Czech Republic - to allocate human rights and freedoms in a separate constitutional

\footnotetext{
${ }^{27}$ Бодян М.В. Система охорони здоров’я в Чеській Республіці. URL : https://www.mif-ua.com/archive/ article/38604.

${ }^{28}$ Шевченко А.С., Кудін С.В. Конституційні засади забезпечення права людини на здоров'я: порівняльно-правове дослідження. Права людини в Україні та у зарубіжних країнах: проблеми теорії та нормативно-правової регламентації : колективна монографія. [За заг. ред. Н. В. Мішиної]. Львів-Торунь : Ліга-Прес, 2020. С. 385 .

29 В Чехии с 22 октября вводят жесткий карантин. URL : https://112.ua/mir/v-chehii-s-22-oktyabryavvoditsya-zhestkiy-karantin-554381.html.
} 
document), to enshrine the state of man and citizen. Equally important is the state's desire to take on the responsibility of caring for the health of vulnerable or vulnerable groups for one reason or another (women (including pregnant women), children, youth, the elderly, and people with disabilities (or people with physical and mental disabilities).

3. The experience of the Polish Republic and the Czech Republic in the field of health care suggests that the following steps should be taken: A) to typologize at the constitutional level of human rights and freedoms of a citizen, and to highlight the block concerning the right to human health (either in the Constitution or through the adoption of a separate act, such as the Basic Law on Human and Civil Rights and Freedoms in Ukraine, having previously held an all-Ukrainian referendum on this issue); B) to enshrine in the Constitution of Ukraine the obligation of the state to take care of the protection of human and civil health with appropriate terminology; C) to amend the Law of Ukraine "Fundamentals of the Legislation of Ukraine on Health Care" in terms of a detailed definition of concepts and terms that reflect all aspects of the right to human health; D) to adopt the Law of Ukraine "On Decentralization of the Health Care System in Ukraine", which clearly prescribes the basic provisions on compulsory public health insurance (in the future - the introduction of a special "medical tax"); At the same time, an inviolable norm should be the provision of free medical services in state and municipal health care facilities on the basis of equality to all citizens of Ukraine, foreigners, stateless persons or dual nationals, refugees, asylum seekers, displaced persons, etc.

4. The experience of controlling the spread of coronavirus infectious disease in the Polish Republic and the Czech Republic may be adapted by the public authorities of Ukraine. In particular, it is the implementation of rather strict measures to implement the conditions of quarantine, as well as strengthening the responsibility for their violation. The example of the authorities in the Czech Republic shows that such preventive measures, although they significantly restrict the rights of citizens, are a serious necessity. But they are aimed at ensuring the human right to health, and on the other hand - allow the state to get out of the economic crisis as soon as possible and return to normal life.

\section{SUMMARY}

The aim of the study is to identify, on the basis of a comparative legal analysis, common and distinctive features of the legislative provision of the human right to health in Ukraine and the Czech Republic and the Republic of Poland. The main task is to generalize the experience of the Czech Republic and Poland, and by considering it - to identify areas for improvement of Ukrainian legislation in this area. It is established that the legislative provision of the right to human health in 
Ukraine is contained not only in the Basic Law, but also in a number of legislative acts, and the analysis of relevant norms shows insufficient perfection of definitions of concepts and terms that should reflect this right. It was revealed that the problems in the field of health care in Ukraine are: the lack of a sustainable Concept for building a new national health care system, the slow pace of health care reform launched in 2017, and the departure from the Soviet centralized health care management system. It was found that the experience of organizing the health care system in the Republic of Poland and the Czech Republic requires amendments to the legislation of Ukraine. It is established that such changes are aimed at: clearer formulation of definitions of basic concepts and terms that define the right to human health, the formation of a decentralized health care system that would meet the basic principles of EU health policy. It was found that the experience of combating the spread of infectious coronavirus in the EU can be adapted by the state authorities of Ukraine.

\section{REFERENCES}

1. Тривалість життя українців все ще найнижча в Європі - соціолог. URL : https://www.radiosvoboda.org/a/29256907.html.

2. Проект Концепції побудови нової національної системи охорони здоров'я України від 07.08.2014 року. URL : http://oblzdrav.mk.gov.ua/index. php/gromadska-rada/obgovorennya/6220-kontseptsiya-pobudovi-novojinatsionalnoji-sistemi-okhoroni-zdorov-ya-ukrajini.

3. Оперативна інформація про поширення коронавірусної інфекції 2019-nCoV. URL : https://moz.gov.ua/article/news/operativna-informacija-proposhirennja-koronavirusnoi-infekcii-2019-ncov.

4. Шевченко А.С., Кудін С.В. Розвиток прав людини в Україні та їх захист державою. Матеріали міжнародної науково-практичної конферениії «Права людини інаціональна безпека: роль органу конституиійної юрисдикиї»» (м. Київ, 27 червня 2019 р.). Київ : КНУ імені Тараса Шевченка. С. 346-353.

5. Anatolii Shevchenko, Olena Kalhanova, Serhii Kudin \& Olena Kravchenko. Guarantees of realization of the rights and freedoms of the person in the national legal system: teaching technique. Asia Life Sciences. The Asian International Journal of Life Sciences. Supplement 21(2) 2019. S. 535-548.

6. Конституція України від 28 червня 1996 року. URL : https://zakon.rada. gov.ua/laws/show/254к/96-вр/.

7. Руснак Л.М. Адміністративно-правове забезпечення права на охорону здоров’я в Україні : дис. ... канд. юрид. наук. Київ, 2016. 207 с.

8. Закон України «Основи законодавства України про охорону здоров'я» від 19.11.1992 р. в редакції від 29.12.2019 p. URL : https://zakon.rada.gov.ua/ laws/show/2801-12. 
9. Закон України «Про забезпечення санітарного та епідеміологічного благополуччя населення〉 від 24.02.1994 р. в редакції від 04.10.2018 р. URL : https://zakon.rada.gov.ua/laws/show/4004-12.

10. Права людини в сфері охорони здоров'я та форми їх захисту. URL : http://korosten-rada.gov.ua/sotsialniy-rozvitok/ohorona-zdorovya/tsentralnamiska-likarnya/prava-lyudini-v-sferi-ohoroni-zdorovya/.

11. Конституційне закріплення права на охорону здоров'я. Порівняльний аналіз конституційної практики. URL : http://bkb-law.com.ua/index.php?option.

12. Швець Ю. Зміст конституційного права особи на охорону здоров'я. Підприємництво, господарство і право. 2017. № 8. С. 135-138.

13. Лещенко В.В., Радиш Я.Ф. Права людини на життя та охорону здоров'я - методологічна основа державного управління здоровоохоронною сферою: вступ до проблеми. Державне управління: теорія та практика. 2014. № 1. C. 104-113.

14. Назарко Ю.В. Гарантії реалізації права на охорону здоров’я в Україні та країнах Європейського Союзу. Юридичний часопис Національної академії внутрішніх справ. 2018. № 1(15). С. 405-418.

15. Роханський А. Права людини в галузі охорони здоров'я. URL : https://helsinki.org.ua/prava-lyudyny-v-haluzi-ohorony-zdorov-ya-a-rohanskyj/.

16. Шамич О.М. Співвідношення права людини на охорону здоров'я i права на життя в Україні. Актуальні проблеми навчання та виховання людей з особливими потребами. 2015. № 12. С. 219-233.

17. Шекера О.Г. Конституційні основи охорони здоров'я громадян в Україні. Збірник наукових пращь співробітників НМАПО імені П.Л. Шупика. 2013. № 22(4). С. 526-533.

18. Національна стратегія побудови нової системи охорони здоров'я в Україні на період 2015-2025 років, розроблена Стратегічною дорадчою групою 3 питань реформування системи охорони здоров'я в Україні. URL : https://healthsag.org.ua/wp-content/uploads/2014/11/Proekt-Strategiyireformi_OZ.pdf.

19. Постанова Верховної Ради України «Про Рекомендації парламентських слухань на тему: «Про реформу охорони здоров'я в Україні» від 21.04.2016 року. URL : https://zakon.rada.gov.ua/laws/show/1338-19.

20. Концепція побудови нової національної системи охорони здоров'я України, анонсована Незалежною експертною платформою «ПРО S VITA» 08.11.2017 року. URL : https://www.ukrinform.ua/rubric-presshall/2335458-novanacionalna-sistema-ohoroni-zdorova-ukraini-koncepcia-vid-pro-s-vita.html.

21. Конституція Польської Республіки (3 передмовою Володимира Шаповала). Київ : Москаленко О.М., 2018. 84 с. 
22. Чмель О., Пустовойт Д., Шмігель А. Аналіз системи охорони здоров’я в Польщі. Сучасні економічні дослідження. 2018. № 1. Вип. 1. С. 13-20.

23. Даневич Б. Медицинская реформа: полезный опыт Польши для Украины (17 октября 2017 г.). URL : https://www.pravda.com.ua/rus/ columns/2017/10/17/7158694/.

24. Президент Польщі підписав спецзакон про боротьбу із коронавірусом. URL : https://nv.ua/ukr/world/countries/koronavirus-u-polshchi-prezident-pidpisavspeczakon-pro-borotbu-z-covid-19-50074399.html.

25. Конституция Чехии (Чешской Республики) от 16 декабря 1992 года. URL : https://czholding.ru/about-cz/konstitucija-chehii/.

26. Достал О. Міжнародний досвід реформування первинної медичної допомоги у Чехії. URL : https://www.umj.com.ua/article/22698/mizhnarodnijdosvid-reformuvannya-pervinnoi-medichnoi-dopomogi-chexiya.

27. Бодян М.В. Система охорони здоров'я в Чеській Республіці. URL : https:// www.mif-ua.com/archive/article/38604.

28. Шевченко А.С., Кудін С.В. Конституційні засади забезпечення права людини на здоров'я: порівняльно-правове дослідження. Права людини в Україні та у зарубіжних країнах: проблеми теорії та нормативно-правової регламентації : колективна монографія. [За заг. ред. Н. В. Мішиної]. ЛьвівТорунь : Ліга-Прес, 2020. 392 с.

29. В Чехии с 22 октября вводят жесткий карантин. URL : https://112.ua/mir/ v-chehii-s-22-oktyabrya-vvoditsya-zhestkiy-karantin-554381.html.

\title{
Information about authors:
} Shevchenko A. Ye.,

Doctor of Law, Professor, Honoured Lawyer of Ukraine, Head of the Department of Theory, History of Law and State and Constitutional Law

University of State Fiscal Service of Ukraine 31, Universytetska str., Irpin, Kyiv region, 08201, Ukraine

\author{
Kudin S. V., \\ Doctor of Law, Associate Professor, \\ Professor at the Department of Theory, History of Law and State and \\ Constitutional Law \\ University of State Fiscal Service of Ukraine \\ 31, Universytetska str., Irpin, Kyiv region, 08201, Ukraine
}

